\title{
In vitro activity of 1,3-bisaryloxypropanamines against Trypanosoma cruzi-infected $L 929$ cultures
}

\author{
Stefânia Neiva Lavorato', Policarpo Ademar Sales Júnior², \\ Silvane Maria Fonseca Murta ${ }^{2}$, Alvaro José Romanha ${ }^{2,3}$, Ricardo José Alves ${ }^{1 /+}$
}

1Departamento de Produtos Farmacêuticos, Faculdade de Farmácia, Universidade Federal de Minas Gerais, Belo Horizonte, MG, Brasil
2Laboratório de Parasitologia Celular e Molecular, Centro de Pesquisas René Rachou-Fiocruz, Belo Horizonte, MG, Brasil
${ }^{3}$ Departamento de Microbiologia, Imunologia e Parasitologia, Universidade Federal de Santa Catarina, Florianópolis, SC, Brasil

We describe herein the antitrypanosomal activity of 20 novel 1,3-bis(aryloxy)propan-2-amine derivatives. Compounds 2, 4, 6, 12, 15, 16 and 19 were significantly active against amastigote and trypomastigote forms, with half maximal inhibitory concentration values in the range of 6-18 $\mu \mathrm{M}$. In the cytotoxicity tests against L929 cells, only compound 4 presented selectivity index value above 10, indicating low toxicity.

Key words: Trypanosoma cruzi - antitrypanosomal agents - Chagas disease - 1,3-bisaryloxypropanamines

Chagas disease, also referred to as American trypanosomiasis, is a neglected tropical disease caused by parasitic protozoa Trypanosoma cruzi. It is estimated that about seven-eight million people are infected by this parasite, mostly in Latin America, where the disease is endemic. The main mode of transmission to people is through faeces of infected triatomine bug left near the site of its bite wound. Due to population migration, an increase in the number of cases has been observed in some countries of North America, Europe and Western Pacific, associated with another ways of transmission, like transfusion of contaminated blood, congenital transmission and organ transplantation (WHO 2014).

There is no available vaccine to use in prevention of Chagas disease. The chemotherapy is restricted to two drugs, nifurtimox (NFX) and benznidazole (BZ), through generation of nitro-reduction intermediates that lead to oxidative stress for NFX or reductive stress for the latter drug (Urbina 2010). Besides, they are effective against acute infections, but show poor activity in the late chronic phase and the increase in cases of resistance and the toxicity associated with the use of these drugs limit the treatment efficacy and patient compliance (Le Loup et al. 2011). Thus, there is an urgent need for new safe and effective drugs that may act at all stages of illness.

Our research group has been interested in identifying the antitrypanosomal potential of several classes of new compounds synthesised in our laboratory (Oliveira et al. 2003, de Oliveira et al. 2006, Júnior et al. 2010). One chemical class that has been explored by our group is that of 1,3-bisaryloxypropanamines, prepared and

doi: 10.1590/0074-02760150007

Financial support: CAPES, CNPq, FAPEMIG, INCT-IF, PDTIS-

FIOCRUZ

+ Corresponding author: ricardodylan@farmacia.ufmg.br

Received 8 January 2015

Accepted 30 April 2015 evaluated initially as potential inhibitors of trypanothione reductase (Silva et al. 2010). A search in the literature revealed that there are only a few reports on these interesting compounds, that display several biological activities, like antifungal (Liu et al. 2000) and antibacterial (Heerding et al. 2003). They were also found to be DNA intercalating agents (Sánches et al. 2013) and sodium channels modulators (Choi et al. 2003). Due to our initial results on trypanothione reductase inhibition and the absence of reports in the literature about antitrypanosomal structurally-related compounds we decided to investigate the potential of this class as antitrypanosomal agents.

Thus, in this paper, we describe the antitrypanosomal activity and cytotoxicity profile of 20 novel 1,3bis(aryloxy)propan-2-amine derivatives (SN Lavorato, unpublished observations) as new candidates for further development as potential antitrypanosomal agents.

Assays with T. cruzi amastigote and trypomastigote forms - For the experiments it was used the Tulahuen strain of the parasite expressing the Escherichia coli $\beta$-galactosidase as reporter gene as previously described (Buckner et al. 1996, Romanha et al. 2010). The compounds were dissolved in dimethyl sulfoxide (DMSO) with the final concentration of the solvent $<1 \%$. Controls with uninfected cells, untreated infected cells, infected cells treated with $1 \mu \mathrm{g} / \mathrm{mL}$ BZ (positive control) and $1 \%$ DMSO were used. The results were expressed as the percentage of $T$. cruzi growth inhibition in compound-tested cells as compared to the infected cells and untreated cells. Quadruplicates were run in the same microplate and the experiments were repeated at least once. The half maximal inhibitory concentration $\left(\mathrm{IC}_{50}\right)$ values were calculated by linear interpolation.

Cytotoxicity over vertebrate L929 cells and selectivity index (SI) - The potential toxicity of the compound to mammalian cells was assayed by the Alamar Blue ${ }^{\circledR}$ as previously described (Romanha et al. 2010). The $50 \%$ cytotoxic concentration $\left(\mathrm{CC}_{50}\right)$ values were calculated by linear interpolation and the SI was determined by ratio $\mathrm{CC}_{50} / \mathrm{IC}_{50}$. 
1,3-bisaryloxypropanamines 1-20 (Table) were evaluated for their antitrypanosomal activity against $T$. cruzi amastigote and trypomastigote forms in just one system, using $\mathrm{BZ}$ as positive control. The results are expressed in the Table as $\mathrm{IC}_{50}$ values. Among tested compounds, only compound 20 , bearing 2-naphthyl group as aromatic ring, was inactive. Several compounds displayed considerable activity, the most active being compounds $2(m-\mathrm{CN})$ and $6\left(p-\mathrm{NO}_{2}\right)$, which presented $\mathrm{IC}_{50}$ of $6 \mu \mathrm{M}$ and $10 \mu \mathrm{M}$, respectively. Compounds $4\left(o-\mathrm{NO}_{2}, \mathrm{IC}_{50}=18\right.$ $\mu \mathrm{M}), 12\left(o-\mathrm{CH}_{3}, \mathrm{IC}_{50}=10 \mu \mathrm{M}\right), 15\left(o-\mathrm{Cl}, \mathrm{IC}_{50}=12 \mu \mathrm{M}\right)$, $16\left(m-\mathrm{Cl}, \mathrm{IC}_{50}=13 \mu \mathrm{M}\right)$ and $19\left(2,3\right.$-benzo, $\left.\mathrm{IC}_{50}=13 \mu \mathrm{M}\right)$ were also significantly active. The less active compound was the unsubstituted 18 , with $\mathrm{IC}_{50}$ of $100 \mu \mathrm{M}$.

Toxicity profiles of active compounds were determined against $\mathrm{L} 929$ cells. They are expressed as $\mathrm{CC}_{50}$ values in the Table. The ratio of $\mathrm{IC}_{50}$ and $\mathrm{CC}_{50}$ values is presented in the same Table as SI, indicating the selective toxicity of each compound. The most selective compound was $4\left(o-\mathrm{NO}_{2}\right)$, with an SI above 11.
Twenty novel 1,3-bis(aryloxy)propan-2-amine derivatives with diverse substitution pattern at the aromatic ring were evaluated. The effect of substituent and its position to antitrypanosomal activity could not be clearly established, since the most active compounds, $2(m-\mathrm{CN})$, $4\left(o-\mathrm{NO}_{2}\right), 6\left(p-\mathrm{NO}_{2}\right), 12\left(o-\mathrm{CH}_{3}\right), 15(o-\mathrm{Cl}), 16(m-\mathrm{Cl})$ and 19 (2,3-benzo), display different physicochemical characteristics. For comparison purposes, the electronic and steric effects of each substituent are represented in the Table by their phenyl substituent constants Hammet's electronic constant and molar refractivity $\left(\mathrm{MR}_{\mathrm{X}}\right)$, respectively, and the hydrophobic properties of each compound by their calculated partition coefficient $(\mathrm{Clog} \mathrm{P})$ values. The hydrophobicity influences the compound ability to cross biologic membranes, that is, to penetrate into the parasite. The electronic character of phenyl substituent affects the $p K a$ of amino group, so the percentage of ionised and nonionised forms of each amine can vary according to the aryl substituent. This could interfere with the ability of crossing cell membranes and

TABLE

In vitro antitrypanosomal activity and cytotoxicity profiles and physiochemical parameters of compounds 1-20

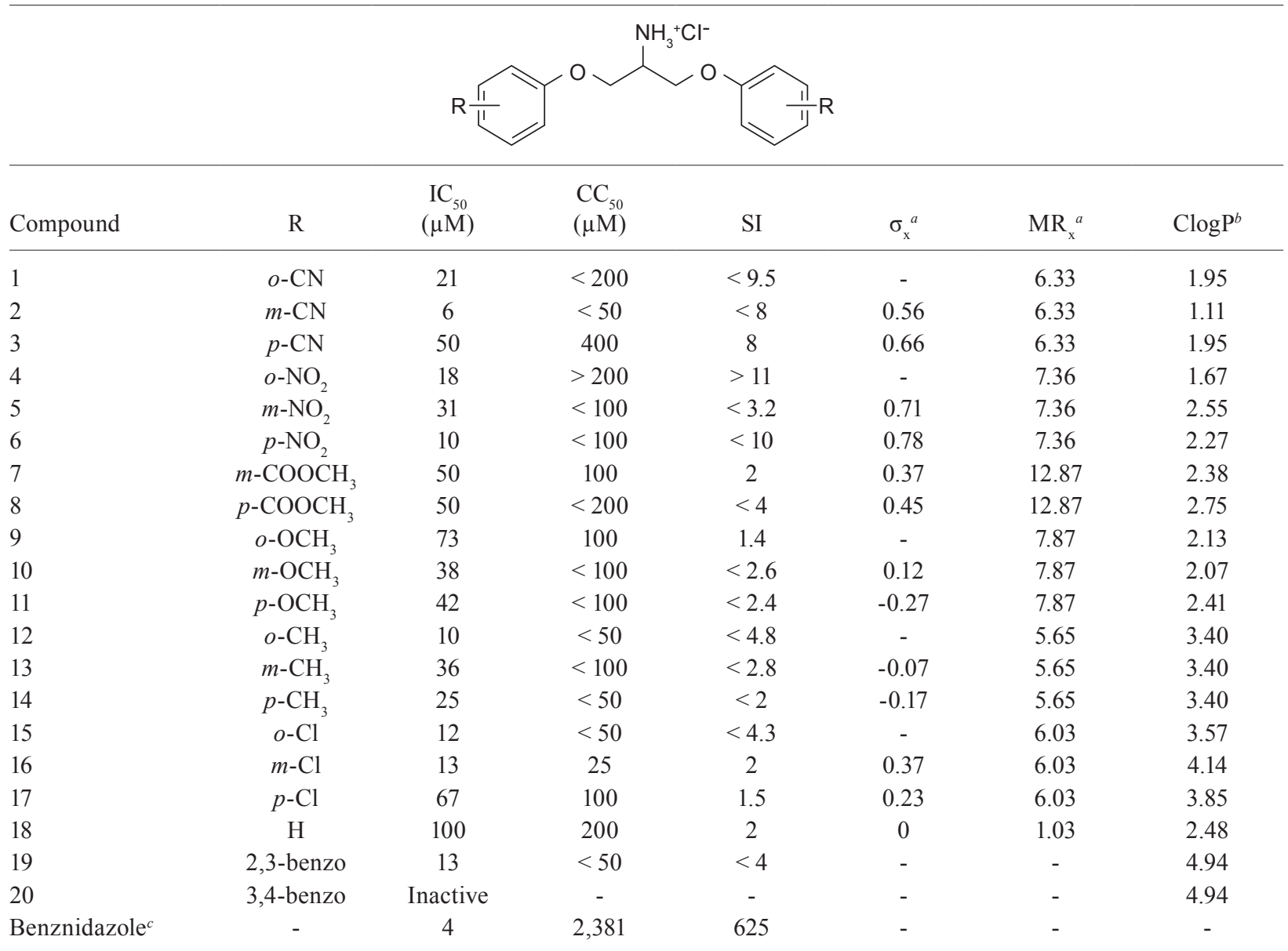

$a$ : obtained from Barreiro and Fraga (2008); $b$ : calculated using ACD/ChemSketch software (acdlabs.com); $c$ : positive control; $\mathrm{CC}_{50}: 50 \%$ cytotoxic concentration; ClogP: calculated partition coefficient; $\mathrm{IC}_{50}$ : half maximal inhibitory concentration; $\mathrm{MR}_{\mathrm{x}}$ : molar refractivity; SI: selectivity index; $\sigma_{\mathrm{x}}$ : Hammet's electronic constant. 
recognition of the compounds by their putative molecular targets and, consequently, on its activity. Besides, the molar refractivity is dependent on volume and polarisability, which can also influence the compound activity. No clear-cut structure-activity relationship can be inferred thus far, however, some observations could be done. For example, the less active compound was the unsubstituted 18, indicating that the introduction of ring substituent contributes to enhance the antitrypanosomal effect. Even though the two best antitrypanosomal compounds, $2\left(m-\mathrm{CN}, \mathrm{IC}_{50}=6 \mu \mathrm{M}\right)$ and $6\left(p-\mathrm{NO}_{2} \mathrm{IC}_{50}=10\right.$ $\mu \mathrm{M})$, are meta or para-substituted, we can notice a prevalence of ortho-substitution pattern among compounds with $\mathrm{IC}_{50}$ below $20 \mu \mathrm{M}$, suggesting that, due to "ortho effect" of substituent (Barreiro \& Fraga 2008), those compounds could assume a particular conformation that improves their activity. Besides, when ortho substituent is introduced, the antitrypanosomal action increases as ClogP increases (Table). So, compounds bearing orthosubstituted aromatic rings with a group that contribute to increase molecular hydrophobicity, like $\mathrm{CH}_{3}$ and $\mathrm{Cl}$, displayed higher activity than those substituted with a group that decrease hydrophobicity, like $\mathrm{NO}_{2}, \mathrm{CN}$ and $\mathrm{OCH}_{3}$. Regarding the meta-substituted compounds, a balance between molecular hydrophobicity and electronic effects of substituent could explain the high activity of compounds $2(m-\mathrm{CN})$ and $16(m-\mathrm{Cl})$. Moreover, analyses suggest that steric effects can also influence the activity of this series, since in general there is an increase in the antitrypanosomal activity as $\mathrm{MR}_{\mathrm{x}}$ value decreases. It was not possible to delineate the influence of physicochemical parameters on para-substituted compounds.

Cytotoxicity profiles of those compounds were also carried out to determine their toxicity on L929 cells. According to Pires et al. (2013), SI value above 10 is recommended to ensure the safety of a drug candidate. In this regard, our compounds, in general, did not present good SI. Among evaluated compounds, only compound 4 (o$\mathrm{NO}_{2}$ ) presented SI value above $10(\mathrm{SI}>11)$, fitting the safety requirement. All compounds bearing $\mathrm{CN}$ group $(1,2$ and 3$)$ and the nitro derivative $6\left(p-\mathrm{NO}_{2}\right)$ exhibited SI values close to 10 , presenting moderate selectivity.

In conclusion, we described herein the antitrypanosomal activity and cytotoxicity profile of 20 novel 1,3-bis(aryloxy)propan-2-amine derivatives. Six new 1,3-bisaryloxypropanamines, $2(m-\mathrm{CN}), 4\left(o-\mathrm{NO}_{2}\right), 6(p$ $\left.\mathrm{NO}_{2}\right), 12\left(o-\mathrm{CH}_{3}\right), 15(o-\mathrm{Cl}), 16(\mathrm{~m}-\mathrm{Cl})$ and 19 (2,3-benzo), were significantly active, with $\mathrm{IC}_{50}$ values in the range of 6-18 $\mu \mathrm{M}$. To the best of our knowledge, this is the first report on the antitrypanosomal activity of this class of compounds. Finally, considering potency and selectivity, compounds $2(m-\mathrm{CN}), 4\left(o-\mathrm{NO}_{2}\right)$ and $6\left(p-\mathrm{NO}_{2}\right)$ appear to be good candidates for further structure modifications.

\section{REFERENCES}

Barreiro EJ, Fraga CAM 2008. Química medicinal: as bases moleculares da ação dos fármacos, 2nd ed., Artmed, Porto Alegre, 536 pp.

Buckner F, Verlinde CLMJ, La Flamme AC, Van Voorhis WC 1996. Efficient technique for screening drugs for activity against Trypanosoma cruzi using parasites expressing galactosidase. Antimicrob Agents Chemother 40: 2592-2597.

Choi S, Fatheree PR, Green DC, Marquess D, inventors. Sodium channel modulators. United States patent US 20030065013 A1. Apr 32003.

de Oliveira RB, Vaz ABM, Alves RO, Liarte DB, Donnici CL, Romanha AJ, Zani CL 2006. Arylfurans as potential Trypanosoma cruzi trypanothione reductase inhibitors. Mem Inst Oswaldo Cruz 101: 169-173.

Heerding DA, Christmann LT, Clark TJ, Holmes DJ, Rittenhouse SF, Takata DT, Venslavsky JW 2003. New benzylidene thiazolidinediones as antibacterial agents. Bioorg Med Chem Lett 13: 3771-3773.

Júnior COR, Alves RO, Rezende CAM, Costa CF, Silva H, Le Hyaric M, Fontes APS, Alves RJ, Romanha AJ, Almeida MV 2010. Trypanocidal activity of lipophilic diamines and amino alcohols. Biomed Pharmacother 64: 624-626.

Le Loup G, Pialoux G, Lescure FX 2011. Update in treatment of Chagas disease. Curr Opin Infect Dis 24: 428-434.

Liu YX, Huang GQ, Li GR 2000. Synthesis and bioactivities of 1,3diaryloxy-2-propylamines. Chinese Journal Synthetic Chemistry 6: $511-515$.

Oliveira RB, Passos APF, Alves RO, Romanha AJ, Prado MAF, de Souza Filho JD, Alves RJ 2003. In vitro evaluation of the activity of aromatic nitro compounds against Trypanosoma cruzi. Mem Inst Oswaldo Cruz 98: 141-144.

Pires CL, Rodrigues SD, Bristot D, Gaeta HH, Toyama DO, Farias WRL, Toyama MH 2013. Evaluation of macroalgae sulfated polysaccharides on the Leishmania (L.) amazonensis promastigote. Mar Drugs 11: 934-943.

Romanha AJ, de Castro SL, Soeiro MNC, Lannes-Vieira J, Ribeiro I, Talvani A, Bourdin B, Blum B, Olivieri B, Zani C, Spadafora C, Chiari E, Chatelain E, Chaves G, Calzada JE, Bustamante JM, Freitas-Junior LH, Romero LI, Bahia MT, Lotrowska M, Soares M, Andrade SG, Armstrong T, Degrave W, Andrade ZA 2010. In vitro and in vivo experimental models for drug screening and development for Chagas disease. Mem Inst Oswaldo Cruz 105: 233-238.

Sánchez MI, Vázquez O, Vázquez ME, Mascareñas JL 2013. Sequence-selective DNA recognition with peptide-bisbenzamidine conjugates. Chem Eur J 19: 9923-9929.

Silva CMG, Raposo CA, Oliveira AC, Uhlein JJ, Lavorato SN, Zani CL, Silva THA, Alves RJ 2010. Synthesis, preliminary biological evaluation and molecular docking studies of diarylamines as potential trypanothione reductase inhibitors. Proceedings of The 5th Brazilian Symposium on Medicinal Chemistry, 2010 Nov 6-9, Ouro Preto, Brazil, SBQ, Ouro Preto, p. 148.

Urbina JA 2010. Specific chemotherapy of Chagas disease: relevance, current limitations and new approaches. Acta Trop 115: 55-68.

WHO - World Health Organization 2014. Chagas disease. Available from: who.int/mediacentre/factsheets/fs340/en/. 